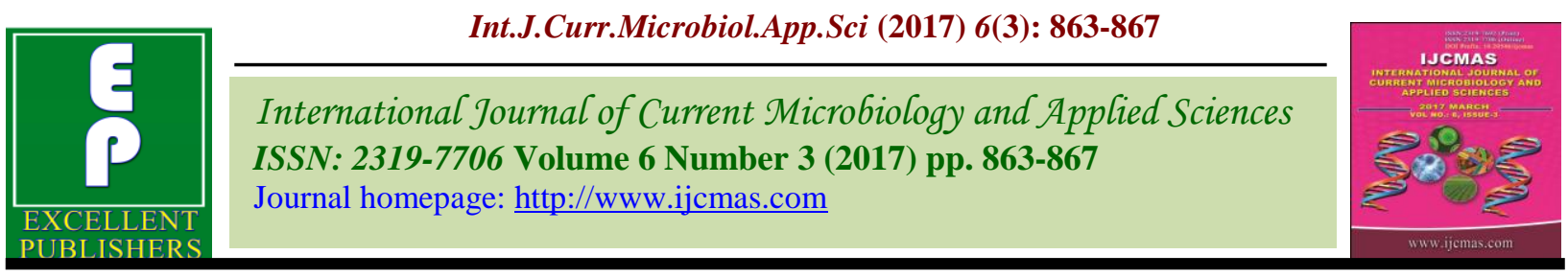

Original Research Article

https://doi.org/10.20546/ijcmas.2017.603.101

\title{
Horizontal and Vertical Diversification of Specialized Homegardens
}

\author{
Allan Thomas and Modem Ravikishore* \\ Department of Agricultural Extension, College of Agriculture, Vellayani, \\ Trivandrum, Kerala, India-695522 \\ *Corresponding author
}

\begin{tabular}{|c|c|}
\hline & A B S T R A C T \\
\hline & \multirow{6}{*}{$\begin{array}{l}\text { This research paper focuses on horizontal and vertical diversification of specialised } \\
\text { homegardens. The study location was Central Kerala region consisting of Thrissur, } \\
\text { Palakkad and Ernakulam districts due to the presence of specialized homegarden system. } \\
\text { A total of } 60 \text { homegarden farmers were selected, to assess the horizontal and vertical } \\
\text { diversification of specialized homegardens. Respondents were personally interviewed and } \\
\text { data were enumerated from the homegardens with components of specializations so as to } \\
\text { get sufficient data from for interpretation. Horizontal diversification is a measure of both } \\
\text { the cropping intensity and the structure of homegardens. Vertical diversification throws } \\
\text { light into the functional dynamics and the economic entities in the homegarden as a result } \\
\text { of value addition or product diversification. Results revealed that there was no } \\
\text { homegardens without any type of horizontal diversification irrespective of the location in } \\
\text { which it belongs. Considering the vertical diversification for both economically dominant } \\
\text { crops and specialized components in homegardens, it is clear that the vertical } \\
\text { diversification is more for the specialized components. In short, this study has gone to } \\
\text { identify horizontal and vertical diversification of specialized homegardens with special } \\
\text { emphasis on different regions of Kerala. }\end{array}$} \\
\hline Keywords & \\
\hline $\begin{array}{l}\text { Diversification, } \\
\text { Farmer, } \\
\text { Homegardens, } \\
\text { Horizontal, Vertical. }\end{array}$ & \\
\hline Article Info & \\
\hline $\begin{array}{l}\text { Accepted: } \\
\text { 15 February } 2017 \\
\text { Available Online: } \\
10 \text { March } 2017\end{array}$ & \\
\hline & \\
\hline
\end{tabular}

\section{Introduction}

Homegardening is an age old practice in various parts of the world and homegardens play an important economic as well as cultural role in rural societies. A typical Kerala homestead consists of a dwelling house with small garden in front and variety of annuals and perennials crops grown in mixture in a small piece of land (KAU, 1989). Agricultural diversification means growing/engaging new to an existing farm/non-farm activities using farm resources (Ali, 2004). The main advantage of the study of diversification in a region lies in the fact that it enables us to understand the impact of physical and socioeconomic conditions on the agriculture.
Moreover, it helps us in knowing the contemporary competition among crops for area, for rotation and effect on double cropping, total production and per hectare productivity (Bhalsing, 2009). The main form and the commonly understood concept is the addition of more crops to the existing cropping system, which could be referred to as horizontal diversification. The other type of crop diversification is vertical crop diversification, in which various other downstream activities are undertaken. This could be illustrated by using any crop species, which could be refined to manufactured 
products, such as fruits, which are canned or manufactured into juices or syrups as the case may be (Devi, 2010). Horizontal diversification is defined as a measure of both the cropping intensity and the structure of homegardens. Vertical diversification throws light into the functional dynamics and the economic entities in the homegarden as a result of value addition or product diversification (Aravind et al., 2004). Zaman (2010) in his study showed that, to get fruits, fuel wood, timber and various agricultural products as well as to bring back equilibrium in the ecosystem, establishment of multi-layered cropping systems in the homesteads and/or orchard is inevitable. Indian agriculture is predominantly a small peasant based economy with approximately $80 \%$ of the operational holdings being below two hectares, and 34\% of the agricultural land are cultivated by them. Because of small operational holdings, it is indeed very difficult by the small farmers to improve their earnings only by raising the yields of the existing crops, mainly cereals (De and Chattopadhyay, 2010). Under these circumstances homegardens are the unique agroforestry systems that needs focus to generate higher income with the available farming land. But there are several constrictions to become successful in homegarden farming system. Understanding horizontal and vertical diversification of homegardens can play a crucial role to overcome the impediments in homegardening. It is in this context a study has taken up on homegardening with the prime focus to explore the horizontal and vertical diversification of specialized homegardens.

\section{Methodology}

The study location was Central Kerala region consisting of Thrissur, Palakkad and Ernakulam districts due to the presence of specialized homegarden system. A total of 60 homegarden farmers were selected for the study through purposive sampling.
Specialized homegardens were identified under 'ICAR Niche Area Excellence Project'. Respondents were personally interviewed during the period of 2013-2014 and data were enumerated from the homegardens with components of specializations so as to get sufficient data from for interpretation.

In this study, the horizontal and vertical diversification was measured as given below:

The horizontal diversification was computed based on the number of levels of crop/specialized component observed in each of the specialized homegardens with special reference to the numerical and economic dominance and the results obtained was recorded in terms of average levels of inclusions in each of the specialized homegardens. Likewise the vertical diversification was computed based on the number of levels of economically dominant crops and the entire specialized components subjected to the levels of value addition until it reaches the market. Thus the extent of horizontal and vertical diversification in specialized homegardens were measured and expressed in percentage and levels of diversification respectively.

\section{Results and Discussion}

Homegardens are unique agroforestry systems with diversified agricultural crops and practices to fulfill the basic needs of the local populations. Horizontal diversification explains the structural aspects whereas vertical diversification throws light into the functional and economical dynamincs of homegarden as a result of product diversification.

The results of extent of horizontal and vertical crop diversification in specialized homegardens are presented in Table 1,2 and 3. 
A perusal of Table 1 clearly shows that there are no homegardens without any type of diversification irrespective of the location in which it belongs. However majority of the homegardens in all the three districts together shows that there was six tiers or more diversification (40 per cent of the specialized homegardens), followed by five tier and four tier diversification (20 per cent each). Thus, it can be deduced unequivocally that 80 per cent of the specialized homegardens had more than four tiers of horizontal diversification. Hence it can be inferred that the majority of the specialized homegardens in the three districts together under study had a four tier or more levels of horizontal diversification which is typical and unique for Kerala homegardens.

Table 2 shows that maximum levels of vertical diversification were observed in coconut (Nuts/ Oil/ Copra), Turmeric/ Ginger (Raw/ Dried/ Powder) and ornamentals (Unit/ Saplings/ Flowers). They are followed by Arecanut, Nutmeg, Rubber, and vegetables with two levels of vertical diversification. Rice, banana and tapioca are having a single level of diversification as grain, fruit and tuber respectively.

A perusal of Table 3 Shows that vertical diversification levels for specialized components in specialized homegarden were found maximum 4 levels for livestock (Milk/Unit/Manure/ Milk products), Aquaculture (Unit/dried/ fingerlings/ processed), and farm tourism (homestay/fishing/leisure/others). It is then followed by rubber nursery (Sheet/ Sap/Saplings), ornamentals (Unit/Seedlings/ flowers), ginger and turmeric (Raw/ Dried/ Powder), mushroom (Raw /Processed/ spawn) and poultry (Unit/ Egg/ Manure) with three levels of diversification. Two levels of vertical diversification are seen in specialized components like organic rice, polyhouse, nutmeg orchard, fruit trees-nursery and terrace farming. Vertical diversification was found least (1) for organic tubers and pineapple.

Considering the vertical diversification for both economically dominant crops and specialized components in the homegardens, it was clear that the vertical diversification is more for specialized components. Thus it can be inferred that inclusion of specialized components in the homegardens can bring in more returns and hence improve the profitability of the specialized homegarden farmer.

Table.1 Distribution of specialized homegardens based on extent of horizontal diversification ( $\mathrm{N}=60$ homegarden farmers)

\begin{tabular}{|c|c|c|c|c|c|c|c|c|}
\hline \multirow{2}{*}{$\begin{array}{l}\text { Horizontal diversification of } \\
\text { numerically and economically } \\
\text { dominant crops }\end{array}$} & \multicolumn{2}{|c|}{ Palakkad } & \multicolumn{2}{|c|}{ Thrissur } & \multicolumn{2}{|c|}{ Ernakulam } & \multicolumn{2}{|c|}{ Total } \\
\hline & No & $\%$ & No & $\%$ & No & $\%$ & No & $\%$ \\
\hline One tier diversification & 0 & 0 & 0 & 0 & 4 & 20 & 4 & 6.67 \\
\hline Two tier diversification & 0 & 0 & 0 & 0 & 2 & 10 & 2 & 3.33 \\
\hline Three tier diversification & 2 & 10 & 2 & 10 & 2 & 10 & 6 & 10.00 \\
\hline Four tier diversification & 4 & 20 & 4 & 20 & 4 & 20 & 12 & 20.00 \\
\hline Five tier diversification & 2 & 10 & 6 & 30 & 4 & 20 & 12 & 20.00 \\
\hline Six tier or more diversification & 12 & 60 & 8 & 40 & 4 & 20 & 24 & 40.00 \\
\hline No diversification & 0 & 0 & 0 & 0 & 0 & 0 & 0 & 0 \\
\hline Total & 20 & 100 & 20 & 100 & 20 & 100 & 60 & 100 \\
\hline
\end{tabular}


Table.2 Extent of vertical diversification for the economically dominant crop in the specialized homegardens

\begin{tabular}{|l|c|c|}
\hline $\begin{array}{c}\text { Economically dominant crop } \\
\text { for all three districts together }\end{array}$ & Levels & $\begin{array}{c}\text { Total } \\
\text { levels }\end{array}$ \\
\hline Coconut & Nuts/Oil/Copra & 3 \\
\hline Arecanut & Nuts/Seedlings(nursery) & 2 \\
\hline Nutmeg & Nuts/Saplings(nursery) & 2 \\
\hline Rubber & Sheet/Saplings & 2 \\
\hline Rice & Grain & 1 \\
\hline Banana & Fruit & 1 \\
\hline Turmeric/Ginger & Raw/Dried/powder & 3 \\
\hline Tapioca & Tuber & 1 \\
\hline Vegetables & Raw/Seedlings & 2 \\
\hline Ornamentals & Unit/Saplings/Flowers & 3 \\
\hline
\end{tabular}

Table.3 Extent of vertical diversification for the specialized components in the specialized homegardens

\begin{tabular}{|l|c|c|}
\hline $\begin{array}{c}\text { Specialized component for all } \\
\text { three districts together }\end{array}$ & Levels & $\begin{array}{c}\text { Total } \\
\text { Levels }\end{array}$ \\
\hline Rubber- Nursery & Sheet/Sap/Saplings & 3 \\
\hline Organic Rice & Grain/Seed & 2 \\
\hline Livestock & Milk/Unit/manure/Milk products & 4 \\
\hline Aquaculture/ Ornamental fish & Unit/dried/fingerlings/Processed & 4 \\
\hline Polyhouse (vegetables) & Raw/Seedlings & 2 \\
\hline Nutmeg orchard & Nuts/Saplings & 2 \\
\hline Ornamentals- Nursery & Unit/Seedlings/Flowers & 3 \\
\hline Ginger and Turmeric- Organic & Raw/Dried/Powder & 3 \\
\hline Fruit trees- Nursery & Fruits/Seedlings & 2 \\
\hline Pineapple & Fruit & 1 \\
\hline Tubers- Organic & Tuber & 1 \\
\hline Mushroom & Raw/Processed/Spawn & 3 \\
\hline Poultry/Ornamental Birds & Unit/Egg/Manure & 3 \\
\hline Terrace farming & Raw/seedlings & 2 \\
\hline Farm tourism & Homestay/Fishing/Leisure/others & 4 \\
\hline
\end{tabular}

Profit enhancement can be realized only if strategies are framed for the farmer respondents so that each specialized homegarden units are attached with more centralized facilities for value addition and product diversification. Homegardens have changed their focus from production and sustainability to income generation, profit and food security. Each homegardens are unique. They are structurally and functionally different from each other. These structural and functional variations should be balanced and maintained so as to obtain so called food security, nutritional security and profit enhancement. 
In conclusion, up until the present, most homegarden studies have focused mainly on species inventories or system description and still little attention has been given to their structural and functional evolution and changes in the functions as a result of specialization. Recent studies undertaken have used analytical methods such as cluster analysis to systematically classify the structure of homegardens. This study shown that high horizontal and vertical diversification among specialized homegardens which clearly indicates understanding horizontal and vertical diversification in homegardens can create more profits to the farming community.

\section{References}

Ali, M. 2004. Agricultural Diversification and International Competitiveness, Tokyo, Japan: The Asian Productivity Organization. http://www.apo-tokyo.org, pp. 1-3.

Aravind, N., Gandharappa, N.R., Ganeshamoorthy, S. and Ibrahim, S. 2004. Article: Homestead agroforestry system. LEIS India, p 21.
Bhalsing, R.R. 2009. Impact of Irrigation on Crop Diversification In: Ahmed Nagar District (Maharashtra) Shodh, Samiksha aur Mulyankan, Int. Res. J., 2(7): 125132.

De, G. and Chattopadhyay, K. 2010. Ag-TiO2 nanoparticle co-doped $\mathrm{SiO} 2$ films on $\mathrm{ZrO} 2$ barrier-coated glass substrates with antibacterial activity in ambient condition, ACS Appl. Mater. Interfaces, 2(9): 2540-2546.

Devi, N.L. and Das, A.K. 2010. Plant species diversity in the traditional homegardens of Meitei community: a case study from Barak Valley, Assam. J. Trop. Agri., 48: 45-48.

Kerala Agricultural University (KAU). 1989. National Agricultural Research Project Status report of the Central zone. Kerala Agricultural University, Thrissur, 1: 1143.

Zaman, S., Siddiquee, S.U. and Katoh. M. 2010. Structure and Diversity of Homegarden Agroforestry in Thakurgaon District, Bangladesh, The Open Forest Sci. J., 3: 38-44.

\section{How to cite this article:}

Allan Thomas and Modem Ravikishore. 2017. Horizontal and Vertical Diversification of Specialized Homegardens. Int.J.Curr.Microbiol.App.Sci. 6(3): 863-867.

doi: https://doi.org/10.20546/ijcmas.2017.603.101 